\title{
The political ontology of protected area co-management: worlding and nature perceptions among stakeholders
}

\author{
Helen Gambon ${ }^{1}$ \\ Patrick Bottazzi \\ University of Bern, Switzerland
}

\begin{abstract}
Political ontology reveals the processes of domination at play in the enactment of realities in a (post-) colonial context. In this article, we illustrate the implications of the power asymmetries inherent in conservation and co-management of protected areas involving Indigenous populations. We do so by exploring the case of Pilón Lajas in the Bolivian Amazon region, an area with double legal status as an Indigenous Territory and Biosphere Reserve. Drawing from our ethnographic fieldwork, we describe how indigenous relational ontology and the modern ontology of 'cultural diversity' are enacted by different stakeholders, and analyse critically the problems that arise for protected area management owing to the domination of a single ontology in a context where different ontologies are enacted. We finish by presenting our argument that solving such problems requires a cognitive justice approach.
\end{abstract}

Keywords: Participation; society-nature relationship; relational ontology; territorial management; resource use; Bolivia

\section{Résumé}

L'ontologie politique révèle les processus de domination en jeu dans la mise en œuvre des réalités dans un contexte (post-) colonial. Dans cet article, nous illustrons les implications des asymétries de pouvoir inhérentes à la conservation et à la cogestion des aires protégées impliquant des populations autochtones. Nous explorons le cas de Pilón Lajas dans l'Amazonie bolivienne, une aire ayant un double statut juridique en tant que territoire autochtone et réserve de la biosphère. En nous appuyant sur notre travail de terrain ethnographique, nous décrivons comment l'ontologie relationnelle autochtone et l'ontologie moderne de la 'diversité culturelle' sont mises en œuvre par les différents acteurs, et nous analysons de manière critique les problèmes qui se posent pour la gestion des aires protégées en raison de la domination d'une seule ontologie dans un contexte où différentes ontologies sont mises en œuvre. Nous terminons en présentant notre argument selon lequel la résolution de ces problèmes nécessite une approche de justice cognitive.

Mot clés: Participation; relation société-nature; ontologie relationelle; gestion du territorie; utilisation des ressources; Bolivie

\section{Resumen}

La ontología política revela los procesos de dominación en juego en la promulgación de realidades en un contexto (post-) colonial. En este artículo ilustramos las implicaciones de las asimetrías de poder inherentes a la conservación y la cogestión de las áreas protegidas en las que participan poblaciones indígenas. Lo hacemos explorando el caso de Pilón Lajas en la Amazonía boliviana, un área con doble condición jurídica como

\footnotetext{
${ }^{1}$ Dr. Helen Gambon, Centre for Development and Environment (CDE), Institute of Geography, University of Bern, Switzerland. Email: helengambon "at" gmail.com. Dr. Patrick Bottazzi, Assistant Professor, Institute of Geography and Centre for Development and Environment (CDE), University of Bern, Switzerland. Email: Patrick.Bottazzi "at" giub.unibe.ch. Acknowledgements: This research was financed by the Swiss National Science Foundation (SNSF) through the Research Module, 'Transcultural Governance of the Environment in Latin America (TransGELA)' (Grant No. PDFMP1_137179). Partial support was also obtained through SNSF grant No. 176736, 'AgroWork'. Thank you to two referees. The authors declare that there are no conflicts of interest to disclose.
} 
Territorio Indígena y Reserva de la Biosfera. A partir de nuestro trabajo de campo etnográfico, describimos cómo la ontología relacional indígena y la ontología moderna de la "diversidad cultural" son promulgadas por diferentes actores, y analizamos críticamente los problemas que surgen para la gestión de las áreas protegidas debido al dominio de una sola ontología en un contexto en el que diferentes ontologías son puestas en práctica. Terminamos presentando nuestro argumento de que la solución de esos problemas requiere un enfoque de justicia cognitiva.

Palabras clave: Participación; relación sociedad-naturaleza; ontología relacional; gestión territorial; uso de recursos; Bolivia

\section{Introduction}

Since the late $20^{\text {th }}$ century, protected areas have been considered a main pillar of the conservation of biodiversity and natural resources (West, Igoe and Brockington, 2006). The initial 'fortress approach' (Galvin and Haller, 2008), where any human influence was considered a threat to the 'pristine wilderness' (Nash, 1967), was criticized in light of research showing that most of these allegedly pristine areas had been used and shaped by local (Indigenous) populations over centuries (Gómez-Pompa and Kaus, 1992; Pimbert and Pretty, 1995). Although biological diversity and cultural diversity are now recognized as inextricably linked (Boillat et al., 2010; IUCN, 1997; Maffi, 2005), most conservation policies continue to present them as separate entities. This separation has a negative impact on protected area management in Bolivia and elsewhere, which is characterized by unsustainable practices of natural resource appropriation and an unsuccessful integration of Indigenous populations into territorial management (Colchester, 2004). To overcome these shortcomings and to increase the efficiency of conservation efforts, participation of local people in decision-making processes and comanagement have become key arguments supporting conservationist approaches (Dovers et al., 2015; Pimbert and Pretty, 1995). It has become widely accepted in conservation science and policy that difficulties in combining Indigenous modes of living and conservation programs are to some extent due to (ethno-) epistemologically divergent views (Coombes, Johnson and Howitt, 2011; Gombay, 2014).

There is an ongoing debate in anthropology comparing the multiple conceptions of the human-nature relationship across Western and non-Western societies (Descola, 2005; Sahlins, 2014; Viveiros de Castro, 1998). This debate tends to oppose a modern and an indigenous ontology. In modern ontology ${ }^{2}$, humans are presented in a position of conceptual and physical domination over the natural world (Howitt and SuchetPearson, 2006). Modern science has long denied the rationality of Indigenous ontologies and classified them under the term 'culture', while considering its own epistemic and ontological position as superior (Blaser, 2013). During the past two decades or so, an 'ontological turn' (Escobar, 2007; Holbraad and Pedersen, 2017) in social theory has challenged the universality of modern assumptions about nature and culture by drawing increased attention to different ontologies and the consequences of how we theorize the constitution of the world (Henare, Holbraad, and Wastell, 2007; Joronen and Häkli, 2017; Scott, 2013).

For instance, the relational ontology of many Amerindian hunter-gatherer societies transcends modern positions on the human-nature relationship and on personhood, by extending agency, intentionality and social institutions to animals, plants, and other "natural" manifestations (Costa and Fausto, 2010; Ingold, 2000; Poirier, 2008; Viveiros de Castro, 1998). Viveiros de Castro (2004a) calls this 'multinaturalism': it is the human condition that is the common element of all societies, not the 'world out there.' This deeply challenges the assumptions underlying modern notions of the opposition of the material world and a multitude of representations, or of the separation of nature and culture (Henare et al., 2007).

A group of researchers defending the ontological turn developed a framework which refers to the politics involved in the co-existence of multiple ontologies that Mario Blaser (2009) calls 'political ontology.' This perspective takes into account not only social perceptions but also their consequences for practices, their performativity and, consequently, the transformation of the world - or ontology - itself (Blaser, 2013). Multiple

\footnotetext{
${ }^{2}$ We acknowledge the great diversity and internal contradictions of the values underlying modern and other ontologies, but for practical purposes, we use those overarching terms in this article as they highlight the fundamental differences in the respective ontological assumptions.
} 
co-existing and enacted ontologies trouble the universal assumption of a common (natural) world and different cultural representations of it. The assumption of a pluriverse is thus necessarily political (Blaser, 2014). 'Worlding' - the enactment of an ontology - cannot be sealed around individuals or ethnic boundaries but should be conceived in a dynamic process of co-habitation, encroachment or hybridization among distinguished groups (Bingham and Hinchliffe, 2008). Blaser (2013: 558) emphasizes that "[w]orlding is a contested, arduous, and not entirely coherent process and never takes place in a vacuum without connections to other ways of worlding. Yet the connections do not cancel their radical differences." Contemporaneous indigeneity can be seen as a 'customization' of modern values, practices and perceptions for strategic reasons (Greene, 2009).

Essentialist and homogenizing narratives fail to shed light on the internal contradictions, incessant processes of transformation and reinterpretations of worlding by Indigenous societies. Such reductionist views are often instrumentalized by various types of activists, leading to what Cepek (2016) called "cosmopolitical risk." Therefore, the co-management of protected areas requires going beyond dichotomist and essentialist theories of the 'modern' vs. 'Indigenous' to allow presenting Indigenous politics more as a complex process of negotiation around ontology and transforming lifeworlds (Gambon and Rist, 2019). Also, political ontology is a theoretical approach revealing the processes of domination at play in the enactment of ontologies in a (post-) colonial context and therefore appears useful in the case of studying protected area co-management.

Political ecology literature usually situates power as originating in a) human agency, b) political economies, c) post-structuralist, discursive power in a Foucauldian sense, or d) a combination of these (Ahlborg and Nightingale, 2018; Svarstad, Benjaminsen and Overå, 2018). In political ontology, power issues are determined by the right to enact a different ontology, and thus a different reality. Political economy long ago claimed interdependence of the recognition of cultural identity and distributive aspects of resource access and, more generally, socio-economic justice (Fraser, 1995; Honneth, 2001). Building on Nancy Fraser's work, environmental justice literature has emphasized the importance of the tripartite typology of concerns recognition, procedure and distribution - as the main vectors of social inclusion in environmental protection (Schlosberg, 2013). In conservation science, cultural recognition has become an essential condition for valorizing local conservation knowledge and supporting collaboration between forest users and conservationists (Berkes, 2012; Zanotti et al., 2020). However, cultural recognition has often been limited to 'respect for culture' within the same modern paradigm (Martin et al., 2016).

Our contribution is an attempt to take a step ahead by showing both the importance and difficulty of moving from a passive recognition of culture to an active recognition of different ontologies through cognitive justice, and practical implications and deep power-based restructuration implied in such a process. Cognitive justice is not a challenge of access to education and legitimated knowledge but the right to enact an ontological disobedience. As Burman (2017) argues, critical attention to ontological power asymmetries allows for better understanding the material power asymmetries at the core of political ecology analyses. Burman (2017: 935) further contends that cognitive injustice and material injustice are "dialectically connected in the sense that the former provides a justification and a naturalization of the latter, and the latter is a material expression of the former."

Conventional approaches to managing protected areas are built on the (modern) assumption that nature can and must be managed by humans (Coombes et al., 2011). Although they have begun to recognize that their way of understanding and perceiving nature may differ from that of Indigenous people, state actors and conservationists view these variations as different cultural representations of a single world out there. The assumption of one natural world and multiple cultural representations of it leads to the idea that conflicts between the state, conservationists and Indigenous peoples on how to manage the environment are epistemological (Gombay, 2014). However, there is growing evidence that many so-called resource conflicts are, in fact, ontological conflicts revolving around different assumptions about reality, and how these manifest in power-laden arenas (Blaser, 2013; Coombes et al., 2011; Howitt and Suchet-Pearson, 2006). Thus, comanagement schemes can be politically charged with contestations about nature(s) if they involve actors from multiple ontological backgrounds (Gombay, 2014).

In this article, we illustrate the implications of the power asymmetries inherent in political ontology for the conservation and co-management of protected areas. We do so by exploring the case of the Pilón Lajas 
Indigenous Territory and Biosphere Reserve (hereafter Pilón Lajas) in the Bolivian Amazon region. The area's double legal status as an Indigenous territory and a protected area provided the basis for the development of a co-management scheme between state authorities and Indigenous peoples. Gambon and Rist (2019) demonstrate the co-existence of multiple ontologies, which can loosely be categorized as naturalist (modern) and relational (perspectivist) ontologies, in Pilón Lajas. In the present article - and following Cepek's critical view on "cosmopolitical risks" - we try to overcome this dichotomy and show that co-management processes are an arena of multiple positions "in between" (modern and perspectivist ontologies) relating to various strategies of positioning, internal contradictions and conflicts among Indigenous and non-Indigenous stakeholders. Three lowland Indigenous peoples - the legal owners of the Indigenous Territory - Andean settlers of Aymara and Quechua origin as well as government agencies and NGOs, which promote nature conservation on one hand and colonization and development of the Bolivian lowlands on the other hand, interact and shape the governance processes in the area and its buffer zone. The ontological power relations between them are so asymmetrical that the perspectivist worlding often remains invisible and unaddressed in comanagement. We first describe how these ontologies are enacted by different stakeholders, focusing on the spaces where they interact and mingle (blurred frontiers between the ontologies). We then proceed to a critical analysis of the problems in protected area management that arise from the domination of a single ontology in a context where different ontologies are enacted. We finish by presenting our argument that solving such problems requires a cognitive justice approach.

\section{Methods}

This research is based on 14 months of fieldwork by the first author in Pilón Lajas between July 2012 and August 2014. This investigation was oriented by previous ethnographic fieldwork carried out by the coauthor in the same area between 2003 and 2011. The research base was in Rurrenabaque, a town of about 13,000 inhabitants, where the Tsimane Mosetene Regional Council (Concejo Regional Tsimane Mosetene, CRTM) and the local office of the National Service for Protected Areas (Servicio Nacional de Areas Protegidas, SERNAP) are located.

To capture the viewpoints and narratives deployed by the co-management institutions, six semistructured interviews were conducted with the directors ${ }^{3}$ of the Biosphere Reserve as well as with park rangers. Five semi-structured interviews were conducted with the CRTM's president, vice-president and the person responsible for land and territory. The interviews were complemented with numerous informal interviews with park rangers and administrative and planning staff of the Biosphere Reserve, as well as with all representatives of the $\mathrm{CRTM}^{4}$ and experts advising them throughout the research period. Further, the first author observed the degree, form and content of the interaction between the CRTM and SERNAP in the facilities shared by these institutions.

The emic perspective of the Mosetene and Tsimane in the least accessible areas of Pilón Lajas was assessed through participatory observation in the communities along the Quiquibey River. A significant amount of time was spent in the Mosetene-dominated communities of Gredal and San Luis Grande ${ }^{5}$, which are respectively located about six hours and one-and-a-half days away from Rurrenabaque by motorized canoe. Shorter visits to six other communities along the Quiquibey River (Bolsón, San Luis Chico, San Bernardo, Corte, Bisal and Asunción del Quiquibey) and one on the Beni River (Charque) complemented the insights into how the Mosetene and Tsimane perceive and interact with their environment.

The main method applied in the communities was participatory observation (DeWalt and DeWalt, 2011; Hammersley and Atkinson, 2007). The first author participated in the daily activities of various women, men and children, which was essential for obtaining consent and building a relationship based on trust that

\footnotetext{
${ }^{3}$ During the research period, the Biosphere Reserve had three directors, two of whom were former park rangers assuming their position ad interim.

${ }^{4}$ The executive committee of the CRTM consists of a president, a vice-president and one person responsible for the issues of land and territory, health, education and gender each.

${ }^{5}$ Household and village size vary significantly over time due to the high mobility of the Mosetene. During the research period, between 8 and 15 adults lived in Gredal, and between 8 and 12 adults lived in San Luis Grande.
} 
established the foundation for conversations and unstructured interviews (Bernard, 2017) on myths, values, worldviews and related resource use practices. Participating in the daily activities of five families in Gredal and four families in San Luis Grande enabled data obtained through conversations and interviews to be validated against people's actions and integrated into observations of the interlocutors' lifeworlds. Conversations were held in Spanish and included discussions of words or concepts used in Mosetene.

\section{Co-management in Pilón Lajas}

The 22 protected areas in Bolivia are not only all inhabited, but half of them intersect and five share a significant surface with Indigenous territories (Fundación Tierra, 2010). One such protected area is Pilón Lajas. The 4,000 $\mathrm{km}^{2}$ area was declared a Biosphere Reserve by the UNESCO Man and Biosphere Programme in 1977 (Surkin, Miranda and Miro, 2010), and in 1992, it was the fifth area to be declared Indigenous Territory by Supreme Decree (No. 23110 Republic of Bolivia). The same decree recognized the region as a biosphere reserve of national interest to preserve biodiversity and the genetic integrity of the area's flora and fauna. The collective property of Indigenous lands was incorporated in 1996 in the national legislation as Native Community Lands (Tierra Comunitaria de Origen, TCO) and recognized in 2009 in the New Political Constitution as Indigenous Native Peasant Territories (Territorios Indígena Originario Campesino, TIOC: Figure 1).

The CRTM was founded in 1991 as a branch of the Tsimane Council, located in San Borja, to ensure territorial claims of the Tsimane and Mosetene communities of Pilón Lajas vis-à-vis the increasing number of colonists and loggers in the Bolivian lowlands. However, as the organization did not function continuously between 1991 and 2001, the Tsimane Council assumed its functions during that time. In 2002, the CRTM was re-established and became independent and is today the only political body representing the Indigenous population of Pilón Lajas (Surkin et al., 2010). The management of the Biosphere Reserve was assumed in the first years by a French NGO. In 1998, the newly created SERNAP took over management responsibilities (Pauquet, 2005).

Co-management in Pilón Lajas did not start until 2004. Based on the area's double legal status, the latest logging concessions within Pilón Lajas were reversed in the late 1990s (Pauquet, 2005), while two oil exploration blocks were halted in 2002 and 2004, respectively (Laats, Inturias and Caymani, 2012). The recognition of common goals between the CRTM and the local SERNAP led to the management committee's decision $^{6}$ in 2004 to develop a joint management plan for the period 2007-2017, the Management Plan and Life Plan (Plan de Manejo y Plan de Vida de la RB-TCO). The joint management plan, which introduced a hitherto unknown model of co-management between the state and Indigenous peoples in Bolivia, was concluded and approved by the Management Committee, the CRTM and the assembly of village leaders ${ }^{7}$ in June 2005 (Surkin et al., 2010). One year later, the Morales administration launched a National Development Plan that provided the basis for the state's future relationships with social organizations, among others, in protected areas, and postulated the active participation of social and productive organizations as well as the co-management of those areas (Ministerio de Planficación del, 2006). The principle of co-management of protected areas was also incorporated in the New Political Constitution of 2009 (Article 385). In accordance with these processes, the management plan for Pilón Lajas was finally approved by the national government at the end of 2008 and published in 2009 (Surkin et al., 2010). An update process started in 2013 and ended in late 2018. The updated management plan was approved by SERNAP and a ministerial resolution in 2019, but the document has yet to be published.

\footnotetext{
${ }^{6}$ The management committee is constituted by representatives from Indigenous organizations, communities, SERNAP and states' authorities (municipalities and prefectures).

${ }^{7}$ The Asamblea de Corregidores is the operative body supporting the CRTM, meeting roughly every four months. The highest (formal) decision-making authority in the TCO, however, is the General Assembly of Communities (Gran Asamblea General de las Comunidades), convened every three years.
} 


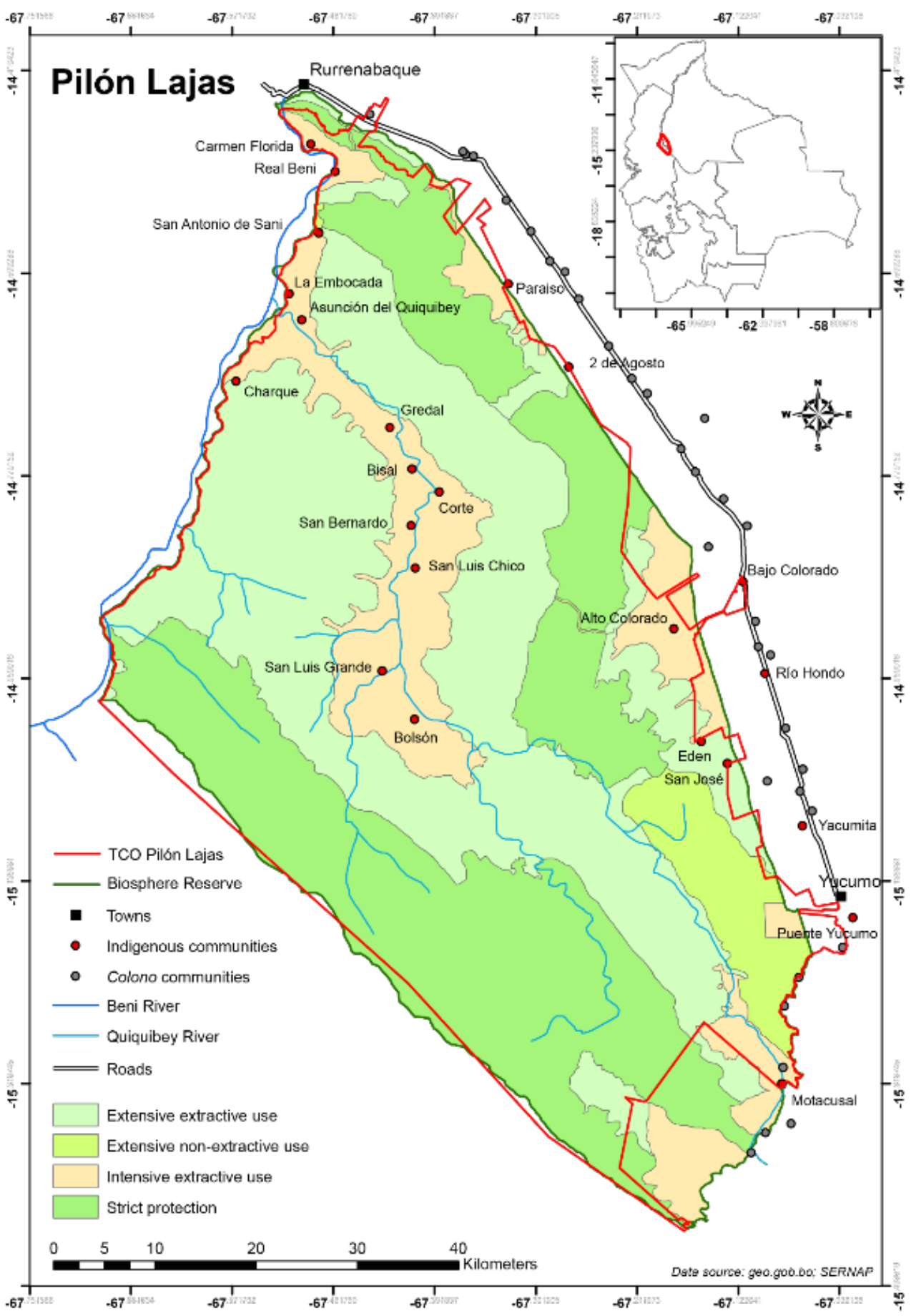

Figure 1: Pilón Lajas Indigenous Territory and Biosphere Reserve (Gambon, 2020) 
Both the park authorities and the CRTM describe co-management as highly beneficial:

This area is characterized by the mutual assistance of the communities and park rangers. With co-management, we can work better than in other protected areas. It favors us greatly. (Director ad interim of the Biosphere Reserve, Rurrenabaque, 2013)

This account has been reproduced in various studies (Costas Monje, 2010; Mariaca, Arteaga and Loayza, 2011; Painter, Duran and Miro, 2011; Surkin et al., 2010) and has proved to be strategically effective for both institutions for raising funds and acquiring development and conservation projects (SERNAP and CRTM interviews). However, previous research indicates that co-management remains conflictive (Gambon and Rist, 2018). We argue that some of these conflicts are rooted in the asymmetric recognition, and thus representation, of different ontologies enacted by the involved stakeholders in the way that co-management is formalized and implemented. In the following subsections, we present three core elements illustrating conflicts based on diverging ways of worlding: (a) participation, (b) territory and (c) 'culture' and resources.

\section{Participation}

In mid-October 2013, a committee consisting of the CRTM board, two environmental NGO consultants to the Indigenous organization and two park rangers of the Biosphere Reserve left Rurrenabaque on a sevenday trip to visit all the communities along the Quiquibey and Beni Rivers. The joint community visit presented a sign of rapprochement between the two institutions after a conflict had erupted the year before, putting a temporary halt to co-management (Gambon and Rist, 2018). The main objective of the tour, which was to be repeated later along the Rurrenabaque-Yucumo road, was to inform the river communities about the initiation of the process for updating the management and life plan for Pilón Lajas, to be completed in 2017. The update was anticipated to affect the objectives for education, health, socio-environmental monitoring, productive projects and the re-zoning of the Biosphere Reserve. A consultant financed by the Wildlife Conservation Society (WCS) and mandated by the CRTM to ensure that the Indigenous population's views and needs were integrated in the updated management plan consulted people to obtain their opinions on the above-mentioned topics, and assess the communities' needs and problems. One of the park rangers urged the community to resume joint patrols - an activity that most consider a vital part of co-management - and most communities agreed to support the park rangers in their work. The meeting concluded after the CRTM shared information on additional topics currently affecting the TCO.

Those meetings revealed key flaws in the participatory process for the development and update of the management plan. One of these flaws concerned exclusion from the decision-making process of entire villages. While the village meeting in Asunción del Quiquibey, the largest community along the Quiquibey River, lasted seven hours, meetings in the smaller communities of Bisal and San Bernardo lasted barely one hour. When asked about the difference in priority given to different communities, the president of the CRTM answered that people in small communities "do not understand anyway" what these meetings are about. Indeed, people in Asunción are generally better educated, as it has its own school up to $8^{\text {th }}$ grade due to its size. Several of the (male) inhabitants have occupied posts at the CRTM and/or SERNAP in the past and are, thus, well versed in both the relational and modern worlds as well as with the categories of conservation and resource management. However, the Tsimane in the smaller communities of Bisal and San Bernardo hardly speak Spanish and have greater difficulty in interacting with the modern world. San Bernardo is home to one of two healers capable of treating spirit-related illnesses recognized in Pilón Lajas. This kind of knowledge is not acquired by the person but is provided by the Wise People, a spirit society considered by some as ancestors. They may take the healer's capacity away if he does not follow the obligations attached to his skills. Despite his important role as a healer, which is inextricably linked to his relationship with the Wise People and non-human societies, his knowledge - based on a relational ontology - is not considered relevant for the elaboration of the new management plan by either conservationists or the CRTM.

Traditionally, a shaman guided the communities with his knowledge, dreams and the advice he received from the Wise People. These days, no one is recognized as having shamanic capabilities (i.e. the ability to 
transform into other beings, see other beings' souls in human shape and negotiate the availability of potential prey with the 'owner' spirits), which points to a disruption in the communication and exchange with the Wise People as a consequence of ontological marginalization (see also Gambon and Rist, 2019). Today's political representation, consisting of a Corregidor for each community and the CRTM representing the TCO is, thus, a relatively new construct ${ }^{8}$ that changes traditional patterns of authority. The CRTM's representatives are mostly young men, while Corregidores are usually middle-aged men, and both are mediating entities - the former between the Indigenous population and the state and the latter between the communities and the CRTM. Nevertheless, they are often accorded decision-making authority by the state, NGOs and researchers. In practice, neither the CRTM nor the Corregidores have decision-making power over the TCO, only the community assembly. However, accountability for the Mosetene and Tsimane is less directed towards other community members than towards other-than-human societies of the forest, meaning that 'human' institutions ultimately have little authority over the inhabitants of Pilón Lajas.

Although the Indigenous population's level of participation has increased with every management plan since the area's creation, their role has tended to remain one of providing information and approval (Bottazzi, 2009). Despite their participation in the socio-economic diagnostic of the area, the participatory mapping of areas in use and consultation regarding problems, constraints, potentials and management objectives, the agenda was clearly set by SERNAP and WCS. The Indigenous population's participation was, and remains limited to, operational aspects: the CRTM and the Indigenous population today participate in activities or decision-making related to management actions, such as joint patrols or specific alternative economic projects. While they have a say in matters related to the economic or social development of the area, decisions related to conservation are taken by SERNAP. As only scientific knowledge of ecosystems is valued, SERNAP and conservation NGOs represent the authority on environmental issues. SERNAP and NGOs have never questioned the supremacy of science over Indigenous knowledge. Thus, a debate on the worldviews and values underlying conservation and resource use has never taken place.

\section{Territory}

I wonder sometimes: are we the owners [of Pilón Lajas] or are we guests? (CRTM - Land and Territory officer, Rurrenabaque, 2014)

Each institution's representatives cited legal arguments for why they should have priority in decisionmaking in the area over the other institution: the CRTM claimed its status as the legal owner of communal lands but conceded rights to SERNAP over the management of the area's resources. SERNAP claimed that the legal provisions defining the area as protected precede the ones defining it as an Indigenous territory ${ }^{9}$, giving the former priority (for an exhaustive understanding of territorial and participatory processes in the Pilón Lajas see Bottazzi, 2014). It must be noted that there exists a legislative gap, as the General Regulations on Protected Areas (Supreme Decree No. 24781, Republic of Bolivia, 1997) do not recognize Biosphere Reserves among the management categories of Bolivian protected areas, and the criteria for planning and management of this type of protected area are not clearly defined. For practical and operational purposes, the Biosphere Reserve is considered equivalent to the management category of Integrated Management Natural Area (Area Natural de Manejo Integrado, ANMI), which is the only conservation category that allows productive activities (Management Plan and Life Plan 2018-2028, unpublished).

Supreme Decree No. 727 (Plurinational State of Bolivia, 2010) established the automatic conversion of TCOs to TIOCs, thus extending collective land tenure to territorial rights (Bottazzi and Rist, 2012). Nevertheless, the inhabitants of Pilón Lajas vehemently oppose the conversion of their TCO to a TIOC, chiefly

\footnotetext{
${ }^{8}$ Between 1804 and 1845, the Franciscan missionaries established Caciques (leaders within the colonial system) in their missions in Alto Beni. Thus, the Mosetene have experienced a longer tradition of this kind of political authority than the Tsimane have (Barba Sanjinez and OPIM, 2010).

${ }^{9}$ Despite being declared a UNESCO Biosphere Reserve in 1977, it was not until 1992 that the Biosphere Reserve was officially recognized in Bolivia via Supreme Decree - the same decree that created the Indigenous Territory.
} 
because it would reduce the bargaining power of the three groups which are indigenous to the area vis-à-vis the settler organizations of the region. The Aymara and Quechua settlers in the transition zone today outnumber the Indigenous population of Pilón Lajas by a 4-to-1 ratio (Bottazzi, 2008, unpublished data provided by CRTM). The settlers have been pushing for the expansion of the agricultural frontier, increasing pressure on Indigenous communities, mainly along the road. The Indigenous population fears that through the conversion of the Pilón Lajas into a TIOC, the settlers could claim access or even property rights.

At the same time, the emic notion of territoriality is based on a relational ontology and the rejection of legal permeability does not extend to social practices. The Tsimane and Mosetene notions of territory are not limited to a single physical space delineated by formal or informal human norms and geometrical boundaries but combine mythical representations, social ties and other-than-human entities as previous studies have documented (Bottazzi, 2014; Daillant, 2003; Ellis, 1997; García Labrador and Ochoa, 2020; Rist, Darr and Bottazzi, 2014). Tsimane have a taste for movement through permanent and long-lasting visit to parents (called sobaqui). The territory becomes a complex web of pathways connecting human and other-than-human (Ellis, 1997) rather than a polygon on a map. Following these interpretations, access to, and use of, natural resources is based on a conceptualization of the environment as constituted through diverse forms of social relationships with and between both human and other-than-human entities, symbols and myths, and extends over the traditionally occupied areas around San Borja, Maniqui River, Alto Beni and beyond (Reyes-García et al., 2014). In this view, the territory is the product of a lived experience in the physical world but also in the symbolic world. Indeed, the Tsimane and Mosetene languages do not possess a word for 'territory.' Our interlocutors were quite puzzled when they had to think of a translation. Jum' jäkh (good land) probably comes closest to the concept of territory. However, when asked about the territory, everybody, from women in the villages to Indigenous leaders to park authorities and conservation NGOs, used the image of the casa grande (big house) to describe Pilón Lajas. Political leaders of the CRTM frequently used it to define a clearly delineated territory with established rules for access and exclusion. Conservationists use it to convey the importance of a respectful engagement with nature to protect the forest as a home for all: Indigenous peoples, animals and plants. Mosetene and Tsimane in the communities incorporated the image in their vocabulary (dursi $\left.a c a^{\prime}\right)$.

However, we argue that the conceptualization of dursi aca' goes beyond that of the conservationists and the CRTM. In the past, the shaman performed rituals asking for good hunting and fishing outcomes in the shipa', a special house usually in the center of the community. Dead kin and other-than-human visitors (e.g. Wise People, owner spirits of the animals and fish, tree spirits) would visit this house and share chicha (fermented manioc beer) with the people. The shipa' was, thus, a place where relationships between the different human and other-than-human societies animating the forest were reinforced and knowledge was exchanged between them (Bottazzi, 2014; Ellis, 1997; Huanca, 1999; Zycherman, 2013). The image of the house as the space in which the connection and affiliation between the diverse forest societies is performed and renewed has been incorporated into community members' conceptualizations of territory. The legal category of the TIOC designed to overcome social fragmentation based on ethnicity - thus, achieves a better conceptualization of the social reality of Indigenous peoples in Bolivia. Nevertheless, the inhabitants of Pilón Lajas perceive it as undermining their bargaining power vis-à-vis highland settlers in determining their way of life and related land use.

With the new challenges of protecting the physical space and managing the resources of Pilón Lajas, the Tsimane and Mosetene have progressively adopted a legal conception of territory based on a polygonal definition (Bottazzi, 2014). There is an overlap between the polygonal and relational worldviews; they are not fundamentally incompatible but can be subject to contradictions or conflicts according to the context. Conflicts appear, for example, over the so-called Indigenous park rangers that have been selected in the communities to work for SERNAP to control hunting and timber extraction, sometimes putting themselves in a critical position with the traditional uses of their own family. Mobility is also at stake, as the Tsimane and Mosetene used to move constantly across the 'borders' to reach their parents or to extract resources. The purpose of 'developing' Pilón Lajas is often in conflict with these territorial practices, as it requires being sedentary from the point of view of modern institutions. 


\section{'Culture' and resources}

I feel that for the park authorities we are just another species that has to be protected from extinction. (former leader of the CRTM, Gredal, 2013).

The aforementioned meeting in Asunción del Quiquibey continued after lunch for the first half-hour or so with only women present. They stated that they needed capacity-building and tools for handicrafts, a rice peeling machine, a corn grinder and a sugar cane press, among other things. Little by little, the men of the community joined the conversation and requested a carpentry workshop, equipment and the enlargement of the school to enable the community's children to graduate from high school. The NGO consultant initiated a brief debate about whether it was appropriate to introduce artefacts that are alien to the local population's culture, such as rice peeling machines. After the women insisted that peeling rice in a tacú (a large wooden mortar) was very tiring and time-consuming, it was decided that this discussion would be postponed.

The discussion about whether the tools that would facilitate women's work would change Mosetene and Tsimane culture not only concerns gender roles and the position of women in both Indigenous and national societies but also the understanding of what constitutes 'culture' and how it is to be 'preserved.' Indigenous women are often described - and describe themselves - as custodians of traditional knowledge and of biodiversity (Deda and Rubian, 2004; Magni, 2017). As such, it seems comprehensible that the NGO consultant asked whether the introduction of new tools would alter the local culture. However, the introduction of tools that would facilitate men's work was not questioned. Chainsaws or motors for boats are increasingly common in the villages, and the requested carpentry workshop was not challenged. This points to an understanding of men as the productive workforce and women as the guardians of culture, whereas culture is considered something tangible. This understanding separates the economic from the socio-cultural, and undermines both the role that men play in maintaining social relationships with other-than-human societies as well as the one that women play in productive activities.

Stakeholders from the modern world defend a rather essentialized and utilitarian notion of Mosetene and Tsimane 'culture' as it appears in the management plans. In this view, cultural aspects are considered valuable mainly if they contribute to the sustainable use of natural resources. Hunting, fishing, gathering and slash-andburn agriculture are presented as the main cultural patterns besides language, perceptions and spirituality in a simplified format. The Management Plan 2018-2028 identifies a range of indicators for the 'cultural evaluation' of the TCO. Extensive knowledge of plant and animal species or soil types in one of the local languages is associated with a higher 'cultural value', as are a range of practices and technologies related to the use of these species. 'Belief-based rules' that regulate access to, use and management of, natural resources and cultural reproduction are other indicators that have been assessed. The assessment states that communities along the Quiquibey River have broader knowledge of hunting and fishing than the road communities do and that they give more practical use to the species. It concludes that in the TCO, the levels of cultural indicators are high, meaning that the 'culture is dynamic, but is reproducing itself' (SERNAP and CRTM, 2019: 127ff).

Apart from being questionable from the methodological viewpoint (e.g. do Andean settlers have less culture because they know and use fewer species?), this cultural evaluation indicates a reduction of culture to material culture. Instead of recognizing relationships that the Mosetene and Tsimane maintain with human and other-than-human entities as pillars of culture, this aspect is wrapped in the category of 'beliefs.' It creates a separation between biodiversity, natural resources and economy, on one hand, and culture, social relationships and worldview, on the other hand - aspects that, in the relational ontology, are closely interconnected.

This separation means that the management plan puts a considerable focus on the development of economic alternatives for Indigenous people and peasant settlers as a key strategy for reducing pressure on natural resources. These projects include ecotourism and the production of non-timber forest products, such as jatata. The economic development projects have proved to be most successful when conducted with peasant settlers, and they regularly fail when implemented with the Mosetene and Tsimane. The numerous failed projects have led many NGO workers and park authorities to conclude that the Mosetene and Tsimane are 'lazy' 
and impossible to work with because, unlike the peasant settlers, they seem not to assume the responsibility of being a counterpart in the projects (Bottazzi, 2014).

One of the main problems at stake, however, is that the Indigenous ways of being-in-place and social organization do not align with the conditions that these projects impose upon the population. The Indigenous way of life adapts to an ever-changing environment with limited predictability. People tend not to set goals and plan ahead but decide each morning what the day's main task will be. These decisions are based, for instance, on the weather conditions but also on the dreams that a person had the night before, e.g. indicating a successful hunting trip. If a bad harvest is foreseeable, families might prefer to visit relatives elsewhere or find temporary wage work along the road. The frequently promoted ecotourism projects or the cultivation of cacao are challenged by the high spatial mobility of Tsimane and Mosetene families.

While resource use in the Mosetene and Tsimane societies is defined by clear social rules, these are rarely enforced by other human beings. Particularly, the Tsimane tend not to confront other people in open conflict. Existing conflicts only become visible when the consumption of large amounts of alcohol is involved or when someone is accused of having bewitched another person (itself a strategy to engage in a conflict). At the core of the norms and rules guiding the access and use of natural resources is the principle of not using more than is needed for one's subsistence. However, other community members do not oppose someone's transgression in fishing, hunting or extracting jatata or other resources. They know that the owner spirits allow fishing, hunting and other resource extraction if it is based on justified needs, and they expect the respective spirit to punish infringers if they are bothered by human actions (see also Bottazzi, 2014; Daillant, 1998, 2003; Gambon and Rist, 2019; Rist et al., 2014). The owner spirits of the fish and the animals will appear to an infringer in a dream to warn him or her that the exceedance must stop. If the person does not follow this warning, he or she will be cursed with illness. The owner spirit may also appear to the infringer as an animal or a person. However, such encounters are highly dangerous, as only shamans are believed to have the capacity to overcome such encounters - that is, to handle a change in perspective. Thus, the social obligations enforced by forest spirits, and particularly the owner spirits and their guardians, are the highest instance regulating resource use and access, above rules established by the communities, the CRTM or the protected area.

These spiritual institutions clearly differ from the current process of territorial management and regulation undertaken by ongoing national reforms and institutions. Such initiatives mainly target a concentration of the Indigenous population in larger, sedentary settlements to facilitate the provision of services, such as healthcare and education, and greater incorporation in the market economy to reduce pressure on the environment caused by hunting and logging. Contrary to the standardized conception of development based on sedentarization and human control, the practices of resource use related to the worlding of Indigenous people are only sustainable if they are connected with dynamic forms of being-in-place - namely, small hamlets connected through kinship and marriage ties that grow and diminish in size in accordance with the environmental conditions. This means that the institutional arrangements that are created or sustained by the management plan aim at transforming Mosetene and Tsimane societies in a way that disconnects them from their ontological foundations of resource use practices. Consequently, the Indigenous population's forms of resource use, considered environment-friendly in principle by the management plan, result in being unsustainable when paired with the institutional arrangements of the nation state and market economy. This is exemplified by a comparison of the communities of Asunción del Quiquibey and San Luis Chico, the most populated (about 20 families and 12 families, respectively) of the eight communities on the Quiquibey River, with the others consisting of one or two extended families. These two communities face more significant environmental issues than the smaller ones. Hunting trips are longer and less successful than in the less populated areas. This increases pressure on non-timber forest products (e.g. it now takes up to four hours to walk to the harvesting areas for jatata from San Luis Chico, while people in smaller communities may reach their harvesting areas within half an hour to an hour's walk), and larger areas of forest are cleared for agriculture. This trend is even more accentuated when comparing riverine communities with Tsimane communities along the Rurrenabaque-Yucumo road. 


\section{Discussion}

The empirical example shows that co-management constitutes an arena in which "uncontrolled equivocations" (Viveiros de Castro, 2004b) between the Indigenous population and the park authorities take place. Uncontrolled equivocation refers to a communicative disjuncture between interlocutors whose ontologies are different and who are unaware that they are enacting different worlds (Blaser, 2009; Viveiros de Castro, 2004b). In this case, these equivocations happen between park authorities and Indigenous peoples. However, the Indigenous population is not homogeneous, and several inhabitants of Pilón Lajas also enact a modern ontology along the relational ontology. People may enact different ontological registers according to the arena in which they are interacting, such as a political or lifeworld arena. In particular, members of the CRTM, who are supposed to assume the position of 'translating agents' between the Indigenous population and the nation state (Bottazzi, 2014), often recreate the power imbalances between the modern and relational ontologies. As a result, they prioritize Indigenous voices that understand and manage 'modern' thinking and arguments and silence those who base their decision-making on dreams and their social relationship with other-than-human societies.

How different ontologies and worldviews become political and lead to conceptual and practical inequalities is a difficult question to answer. Simple 'respect for cultural diversity' is not a sufficient step forward to include social justice in conservation issues (Martin et al., 2016). The subtle or naïve inclusion of 'cultural patterns' in Westernized management processes can, as we have seen, play against the full recognition of a more complex and comprehensive worlding. By breaking the full ontological structure, and consequently its profound signification, by reassigning cultural tasks by age, gender and level of education, or by omitting the social aspects of human-nature interactions, the co-management process enacts a symbolic violence on Indigenous communities that can be more destructive than complete spatial exclusion.

The modern world and the actors representing it - including, in many instances, the CRTM - are so much more powerful than the perspectivist world and those that enact it that Indigenous worldviews have become almost non-existent. Although the management plans emphasize Tsimane and Mosetene 'harmonious life with nature', it remains limited to a modern dualist representation of space rather than allowing the Indigenous population to present their own contradictions and/or complex ontologies. Such expression of complexity would be only possible through a process of creating completely new spaces of political dialogue rather than including Indigenous people into existing spaces. This aspect would not only lead to overcoming the notion of 'representative democracy' rooted in Western principles and build new mechanisms of dialogue valuing multiple ontologies (Martin et al., 2016) but also reduce the risk of the state and conservationists coopting the Indigenous organization through established forms of participation (Ferguson, 1994; Gambon and Rist, 2018).

Political representation of Indigenous populations is based on 'modern' premises of organization, and the CRTM's members and the corregidores enact, jointly with SERNAP, a modern imaginary of outcome-oriented resource management (improved biodiversity conservation). At the same time, the very same people also enact a relational, process-oriented reality in which the notion of 'management' can best be described as the management of social relations. Contexts of complex ontological diversity dismantle the clear distinctions between nature and culture, human and non-human, modern and relational (Umans and Arce, 2014). We call this blurredness the simultaneity of the non-simultaneous after Bloch (1962), who used it to analyze the ideological crisis of the 1930s. According to him, people can physically live in one time and culturally and cognitively in an earlier time. Here, we use this concept to describe how people can live in both a relational and a modern reality, enacting both ontologies.

To what extent can ontological differences be merged or hybridized before becoming mere cultures at the service of a supposedly common world dominated by Western knowledge? This case study shows that ontologies are not fixed categories that can be described and catalogued, and ontology does not just replace the concept of culture (Blaser, 2014). The blurred borders between ontologies - and thus the ontologies themselves - are constantly re-negotiated through inter-ontological interaction (Blaser, 2009; Harris and Robb, 2012). One result of such interaction can be seen, for instance, in the Bolivian state, which has endeavored to incorporate indigenous ethical principles, territoriality and governance into the national constitution, applied at the local 
level. Conceptualizing indigeneity is, nevertheless, a difficult task for a state, and many tend to invoke essentialized imaginaries of local, place-based and traditional (and thus static) communities (Coombes et al., 2011; McCreary and Milligan, 2014). Although Bolivia has certainly gone a long way to recognize Indigenous rights, recognition also tends to normalize ontologies. Difference, then, again becomes a different way of knowing instead of a different reality influencing not only the use of land and natural resources, but also governance and being-in-place (Fraser, 1995; Honneth, 2001; Martin et al., 2016; McCreary and Milligan, 2014; Schlosberg, 2013).

Although many local communities have developed common property resource management systems that can sustain both livelihoods and fundamental ecological processes, these institutions are being challenged by the modern state, market and demographic pressures (Belsky, 2000). These constraints are also apparent in Pilón Lajas. Although the TCO covers an area of 346,126 hectares, 37\% of its surface has been declared areas of strict protection, making it (theoretically) inaccessible to the Indigenous population. Increased population density related to the concentration in larger settlements and general population growth reduce the sustainability of the practices of Mosetene and Tsimane. They, too, must find solutions to deal with changing land use patterns resulting from inter-ethnic marriages with peasant settlers, tenure individualization tendencies in communities along the road, and the call for formal education and the related loss of knowledge (Bottazzi, 2014) that is needed to re-enact the Indigenous worlding. This is because in the end, the goal of conservationists and Indigenous people is the same: to maintain a 'healthy environment.' It is the different motivations and significations behind this goal that render co-management so difficult. There is a historically determined power imbalance between the Western modern ontological perspectives underpinning the currently dominant biocentric views of park management and the relational worldview of the Indigenous population. This leads to a situation where advocates of the modern ontology claim the universal authority to define the meanings of 'healthy' and 'environment.'

The case of Pilón Lajas shows that if co-management (or participation of local communities in conservation efforts in general) is to be successful, political ownership of the participation process is not sufficient. Ownership must pervade the spheres of worlding, enacting, space and practice (Haller, Acciaioli and Rist, 2016; Liechti, Wallner and Wiesmann, 2010). We propose a cognitive justice approach to contribute to the solution of political ontology problems. De Sousa Santos (2012; 2007) argues that the privilege and dominance of Eurocentric systems of knowledge in relation to other ways of knowing the world creates injustices that can only be overcome by epistemological dialogues. Burmann (2017: 925) expands the concept of cognitive justice to the realm of ontology by asking "whose reality is allowed to be real?" Such a cognitive justice approach goes beyond participation, by recognizing the plurality of realities (and related knowledge systems) and the connections between ontology and lifeworlds (Visvanathan, 2005). A dialogue on contrasting, competing or complementing ontologies must be structured such that it ensures the right of different ways of worlding to enter the spaces of decision-making but, more importantly, the quality of the space into which different ways of worlding enter (Reilly, 2013). It is important to note that cognitive justice "does not (...) relegate science to an uncritical domain of equally valid knowledges. Instead, it calls for a confrontation of science with other ways of knowing the world, towards more responsible dialogues on what knowledge forms the basis for just, sustainable and peaceful development" (van der Velden, 2009: 44).

Beisel and Jaeger (2007) propose fluidity as a design principle for cognitive justice, while van der Velden (2009) suggests adaptability. Similarly, Umans and Arce (2014) propose a 'go-with-the-flow' approach for contexts where ontologies encounter and interact - an approach based on fluidity and blurredness. Van der Velden (2005) compares cognitive justice processes to diversity in ecological systems, influencing the system's ability and capacity to adapt to change and solve problems. She argues that outcomes of cognitive justice processes are more flexible (accommodating diverse interests) and more democratic (incorporating different values). Cognitive justice is, thus, fundamental if sustainability is understood not as an end state to reach but as an ongoing social learning process. This view on sustainability recognizes change over temporal and spatial scales and involves complex inter-ontological interactions and feedback (Cornell et al., 2013). However, there is no prescription for what a management plan for the Pilón Lajas Biosphere Reserve and Indigenous Communal Lands would look like if developed by following a cognitive justice approach. Indeed, it will be challenging to translate and incorporate the often invisible, intangible and transforming elements of relationalism into 
administrative processes. For instance, co-management based on cognitive justice raises the question of whether and to what extent other-than-human societies have to be integrated in participatory processes.

The focus of the management plan should be less on the outcomes, i.e. biodiversity conservation and economic development, but on an inclusive decision-making process, accommodating the blurredness and fluidity inherent in ontological pluralism (Muller, 2014; Suchet-Pearson, Wright, Lloyd, and Burarrwanga, 2013).

\section{Conclusion}

Co-management in the Pilón Lajas Indigenous Territory and Biosphere Reserve over the last decade has had positive impacts on biodiversity conservation and environmental sustainability on one hand, and on territorial rights and the organizational capacity of the CRTM on the other. However, co-management has also created a political arena in which park authorities, policymakers, experts and Indigenous leaders establish the norms of governance and management. This political arena is entirely based on mononatural and multicultural assumptions: the world is a single one and different cultural perceptions of it can be brought in line through comanagement institutions. The Indigenous leaders have become part of this arena of action by being embedded in it. For many community members, however, the relationship with 'natural resources' is primarily a social one, as 'nature' has agency and intentionality. One's position in the world is not always as it appears, as the point of view creates the subject, not the object (Viveiros de Castro, 1998). The Mosetene and Tsimane, thus, enact a multinaturalist and monocultural world. While park management as perceived from a mononatural perspective entails the management of resources and is outcome oriented, territorial management from a multinatural perspective is concerned with the maintenance of social relationships and is process oriented.

Taking political ontology seriously means that theorization of power needs to be reconceptualized and extended to other-than-human stakeholders - and the environment not just considered as consisting of 'resources' over which access and control are negotiated, but as (an) actor(s) with agency and intentionality. Cognitive justice goes beyond a simple recognition of cultural identities, by announcing the responsibility of scientific agents, conservationists and practitioners to make huge epistemological efforts to question deeprooted assumptions about the constitution of the world. Cognitive justice calls for a recognition of ontological diversity. The uncovering of ontological power imbalances and the reconciliation of realities potentially yields promising outcomes in biodiversity conservation, in recognition of Indigenous rights, and in reduction of environmental conflicts.

\section{References}

Ahlborg, H., \& Nightingale, A. J. (2018). Theorizing power in political ecology: the 'where' of power in resource governance projects. Journal of Political Ecology, 25(1), 381-401. https://doi.org/10.2458/v25i1.22804

Barba Sanjinez, I. A., \& OPIM. (2010). Tsinsi tsä'si, tsinsi chhutyitidye: Nuestra vida, nuestros conocimientos. Ministerio de Educación, La Paz.

Beisel, U., \& Jaeger, M. (2007). Powerless networks? The implementation of decentralised technologies in Madagascar. In A. Bora, S. Bröchler, \& M. Decker (Eds.), Technology Assessment in der Weltgesellschaft. Edition Sigma.

Belsky, J. M. (2000). Changing human relationships with nature: Making and remaking wilderness science. Paper presented at the Wilderness science in a time of change conference-Volume 1: Changing perspectives and future directions, Ogeden.

Berkes, F. (2012). Sacred ecology. Routledge.

Bernard, H. R. (2017). Research methods in Anthropology: Qualitative and quantitative approaches. AltaMira Press.

Bingham, N., \& Hinchliffe, S. (2008). Reconstituting natures: Articulating other modes of living together. Geoforum, 39(1), 83-87. doi:10.1016/j.geoforum.2007.03.008

Blaser, M. (2009). Political ontology. Cultural Studies, 23(5-6), 873-896. doi:10.1080/09502380903208023 
Blaser, M. (2013). Ontological conflicts and the stories of peoples in spite of Europe. Current Anthropology, 54(5), 547-568. doi:10.1086/672270

Blaser, M. (2014). Ontology and indigeneity: on the political ontology of heterogeneous assemblages. Cultural Geographies, 21(1), 49-58. doi:10.1177/1474474012462534

Bloch, E. (1962). Erbschaft dieser Zeit (Vol. 4). Suhrkamp.

Boillat, S., Castillo, J., Alvarez, A., Bottazzi, P., Camacho, D., Serrano, E., . . Rist, S. (2010). Protected areas and indigenous peoples in Bolivia and Peru: Dilemmas, conflicts, and ways out. In H. Hurni \& U. Wiesmann (Eds.), Global change and sustainable development: A synthesis of regional experiences from research partnerships (vol 5 pp. 501-515). Geographica Bernensia.

Bottazzi, P. (2008). Linking" socio" and" bio"diversity: The stakes of indigenous and non-indigenous comanagement in the Bolivian lowlands. In M. Galvin \& T. Haller (Eds.), People, Protected Areas and global change: Participatory conservation in Latin America, Africa, Asia and Europe (pp. 81-109). Swiss National Centre of Competence in Research (NCCR) North-South.

Bottazzi, P. (2009). Indigenous governance, protected areas and decentralised forestry: a comparative analysis of two Tsimane'territories in the Bolivian Lowlands. Swiss National Centre of Competence in Research (NCCR) North-South. https://serval.unil.ch/resource/serval:BIB_6E1110D56BD9.P001/REF.pdf

Bottazzi, P. (2014). Une écologie politique des territoires tsimane' d'Amazonie bolivienne: "notre grande maison." Karthala / Graduate Institute Publications.

Bottazzi, P., \& Rist, S. (2012). Changing land rights means changing society: The sociopolitical effects of agrarian reforms under the government of Evo Morales. Journal of Agrarian Change, 12(4), 528-551. doi:10.1111/j.1471-0366.2012.00367.x

Burman, A. (2017). The political ontology of climate change: moral meteorology, climate justice, and the coloniality of reality in the Bolivian Andes. Journal of Political Ecology, 24(1), 921-938. https://doi.org/10.2458/v24i1.20974

Cepek, M. L. (2016). There might be blood: Oil, humility, and the cosmopolitics of a Cofán petro-being. American Ethnologist, 43(4), 623-635. doi:10.1111/amet.12379

Colchester, M. (2004). Conservation policy and indigenous peoples. Environmental Science and Policy, 7(3), 145-153. doi:10.1016/j.envsci.2004.02.004

Coombes, B., Johnson, J. T., \& Howitt, R. (2011). Indigenous geographies I: Mere resource conflicts? The complexities in indigenous land and environmental claims. Progress in Human Geography, 36(6), 810821. doi:10.1177/0309132511431410

Cornell, S., Berkhout, F., Tuinstra, W., Tàbara, J. D., Jäger, J., Chabay, I., de Wit, B., Langlais, R., Mills, D., Moll, P., Otto, I. M., Petersen, A., Pohl, C., van Kerkhoff, L. (2013). Opening up knowledge systems for better responses to global environmental change. Environmental Science and Policy, 28, 60-70. doi:10.1016/j.envsci.2012.11.008

Costa, L., \& Fausto, C. (2010). The return of the animists: Recent studies of Amazonian ontologies. Religion and Society: Advances in Research, 1(1), 89-109. doi:10.3167/arrs.2010.010107

Costas Monje, P. (2010). La pluriterritorialidad en el Norte de La Paz: Dos estudios de caso sobre la defensa del territorio (pp. 145-172). Fundacion Tierra.

Daillant, I. (1998). Ils sont comme nous, mais ... Relations de parenté et de genre entre Chimane et "gens de dedans". Anthropologie et Sociétés, 22(2), 75-97.

Daillant, I. (2003). Sens dessus dessous: Organisation sociale et spatiale des Chimane d'Amazonie bolivienne. Nanterre: Societé d'Ethnologie.

de Sousa Santos, B. (2012). Public sphere and epistemologies of the south. Africa Development, 31(1), 43-67.

de Sousa Santos, B., Arriscado Nunes, J., \& Meneses, M. P. (2007). opening up the canon of knowledge and recognition of difference. In B. de Sousa Santos (Ed.), Another knowledge is possible. Beyond Northern epistemologies. Verso. 
Deda, P., \& Rubian, R. (2004). Women and biodiversity: The long journey from users to policy-makers. Natural Resources Forum, 28, 201-204. http://doi.org/10.1111/j.1477-8947.2004.00089.x

Descola, P. (2005). Par-delà nature et culture. Gallimard.

DeWalt, K. M., \& DeWalt, B. R. (2011). Participant observation: A guide for fieldworkers. AltaMira Press.

Dovers, S., Feary, S., Martin, A., McMillan, L., Morgan, D., \& Tollefson, M. (2015). Engagement and participation in Protected Area management: Who, why, how and when? In G. L. Worboys, Lockwood M., Kothari A., Feary S., \& Pulsford, I. (Eds.), Protected Area governance and management (pp. 413440). ANU Press.

Ellis, R. (1997). A taste of movement: An exploration of the social ethics of the Tsimanes of Lowland Bolivia. PhD dissertation. University of St. Andrews.

Escobar, A. (2007). The 'Ontological Turn' in social theory: A commentary on 'Human geography without scale' by Sallie Marston, John Paul Jones II and Keith Woodward. Transactions of the Institute of British Geographers, 32(1), 106-111.

Ferguson, J. (1994). The anti-politics machine: Development, depoliticization, and bureaucratic power in Lesotho. University of Minnesota Press.

Fraser, N. (1995). From redistribution to recognition? Dilemmas of justice in a 'post-socialist' age. New Left Review, 212, 68-68.

Fundación Tierra. (2010). Reconfigurando territorios. Reforma agraria, control territorial y gobiernos indígenas en Bolivia. Fundacion Tierra.

Galvin, M., \& Haller, T. (2008). People, protected areas and global change: participatory conservation in Latin America, Africa, Asia and Europe (Vol. 3): Swiss National Centre of Competence in Research (NCCR) North-South. https://www.participatorymethods.org/resource/people-protected-areas-andglobal-change-participatory-conservation-latin-america-africa

Gambon, H. (2020). Constitutionality processes and social-ecological dynamics in the Pilón Lajas Indigenous Territory and Biosphere Reserve. PhD Dissertation, University of Bern.

Gambon, H., \& Rist, S. (2018). Moving territories: Strategic selection of boundary concepts by Indigenous People in the Bolivian Amazon - an element of constitutionality? Human Ecology, 46, 27-40. doi: $10.1007 / \mathrm{s} 10745-017-9960-\mathrm{z}$

Gambon, H., \& Rist, S. (2019). Worldview matters: Mosetene ontology and resource use in the Pilón Lajas IndigenousTerritory and Biosphere Reserve in the Bolivian Amazon. Human Organization, 78(1), 5463. https://doi.org/10.17730/0018-7259.78.1.54

García Labrador, J., \& Ochoa, J. (2020). Two ontologies of territory and a legal claim in the Ecuadorian Upper Amazon. Journal of Political Ecology, 27(1), 496-516. doi:10.2458/v27i1.23099

Gombay, N. (2014). 'Poaching' - What's in a name? Debates about law, property, and protection in the context of settler colonialism. Geoforum, 55, 1-12. doi:10.1016/j.geoforum.2014.04.010

Gómez-Pompa, A., \& Kaus, A. (1992). Taming the wilderness myth. BioScience, 42(4), $271-279$. https://doi.org/10.2307/1311675

Greene, S. (2009). Customizing indigeneity: paths to a visionary politics in Peru. Stanford University Press.

Haller, T., Acciaioli, G., \& Rist, S. (2016). Constitutionality: Conditions for crafting local ownership of institution-building processes. Society \& Natural Resources, 29(1), 68-87. doi: $10.1080 / 08941920.2015 .1041661$

Hammersley, M., \& Atkinson, P. (2007). Ethnography: principles in practice. Routledge.

Harris, O. J. T., \& Robb, J. (2012). Multiple ontologies and the problem of the body in history. American Anthropologist, 114(4), 668-679. doi:10.1111/j.1548-1433.2012.01513.x

Henare, A., Holbraad, M., \& Wastell, S. (2007). Introduction. In A. Henare, M. Holbraad, \& S. Wastell (Eds.), Thinking through things: Theorising artefacts ethnographically (pp. 1-31). Routledge.

Holbraad, M., \& Pedersen, M. A. (2017). The ontological turn: an anthropological exposition: Cambridge University Press. 
Honneth, A. (2001). Recognition or redistribution? Changing perspectives on the moral order of society. Theory, Culture \& Society, 18(2-3), 43-55.

Howitt, R., \& Suchet-Pearson, S. (2006). Rethinking the building blocks: Ontological pluralism and the idea of 'management'. Geografiska Annaler, Series B: Human Geography, 88(3), 323-335. doi:10.1111/j.14680459.2006.00225.x

Huanca, T. (1999). Tsimane' indigenous knowledge, swidden fallow management, and conservation. PhD dissertation. University of Florida.

Ingold, T. (2000). The perception of the environment: Essays on livelihood, dwelling and skill. Routledge.

IUCN. (1997). Indigenous Peoples and Sustainability. Cases and Actions: IUCN Intercommission Task Force on Indigenous Peoples, International Books.

Joronen, M., \& Häkli, J. (2017). Politicizing ontology. Progress in Human Geography, 41(5), 561-579. doi:10.1177/0309132516652953

Laats, H., Inturias, M. L., \& Caymani, C. (2012). Megaobras en Madidi y Pilón Lajas. Hacia una transformación de los conflictos. Embajada Real de Dinamarca, Fundación PIEB.

Liechti, K., Wallner, A., \& Wiesmann, U. (2010). Linking a World Heritage site to sustainable regional development: Contested natures in a local negotiation process. Society and Natural Resources, 23(8), 726-741. doi:10.1080/08941920802449011

Maffi, L. (2005). Linguistic, cultural, and biological diversity. Annual Review of Anthropology, 34, 599-617.

Magni, G. (2017). Indigenous knowledge and implications for the sustainable development agenda. European Journal of Education, 52, 437-447. doi:10.1111/ejed.12238

Mariaca, J., Arteaga, L., \& Loayza, O. (2011). Sistematizacion de una experiencia de gobernanza de territorio indigena sobrepuesto con un area protegida. La reserva de la biosfera y tierra comunitaria de origen Pilon Lajas - Bolivia. Informe de consultoría. ILSA.

Martin, A., Coolsaet, B., Corbera, E., Dawson, N. M., Fraser, J. A., Lehmann, I., \& Rodriguez, I. (2016). Justice and conservation: The need to incorporate recognition. Biological Conservation, 197, 254-261. doi:10.1016/j.biocon.2016.03.021

McCreary, T. A., \& Milligan, R. A. (2014). Pipelines, permits, and protests: Carrier Sekani encounters with the Enbridge Northern Gateway Project. Cultural Geographies, 21(1), 115-129. doi:10.1177/1474474013482807

Ministerio de Planficación del, D. (2006). Plan Nacional de Desarrollo: Bolivia digna, soberana, productiva y democrática para Vivir Bien. La Paz.

Muller, S. (2014). Co-motion: Making space to care for country. Geoforum, 54, $132-141$. doi:10.1016/j.geoforum.2014.04.011

Nash, R. (1967). Wilderness and the American mind. Yale University Press.

Painter, R. L., Duran, A., \& Miro, E. (2011). Indigenous alliances for conservation in Bolivia. Conservation Biology, 25(6), 1084-1086. doi:10.1111/j.1523-1739.2011.01767.x

Pauquet, S. (2005). Diagnosis of the Pilon Lajas Biosphere Reserve and Communal Lands. ParksWatch-Bolivia.

Pimbert, M. L., \& Pretty, J. N. (1995). Parks, people and professionals: Putting "participation" into protected-area management. United Nations Research Institute for Social Development.

Plurinational State of Bolivia. (2010). Supreme Decree No. 727: President-in-Office Alvaro Marcelo García Linera. Retrieved from: https://www.lexivox.org/norms/BO-DS-N727.xhtml?dcmi_identifier=BO-DSN727\&format $=x h t m l$

Poirier, S. (2008). Reflections on indigenous cosmopolitics-poetics. Anthropologica, 50(1), 75-85.

Reilly, K. M. A. (2013). Open data, knowledge management, and development. In M. L. Smith \& K. M. A. Reilly (Eds.), Open development: Networked innovations in international development. MIT Press.

Republic of Bolivia. (1992). Supreme Decree No. 23110: President Jaime Paz Zamora. Retrieved from: https:/www.lexivox.org/norms/BO-DS-23110.xhtml?dcmi_identifier=BO-DS-23110\&format=xhtml 
Republic of Bolivia. (1997). Supreme Decree No. 24781: President Gonzalo Sánchez de Lozada. Retrieved from: $\quad$ https://www.lexivox.org/norms/BO-DS-24781.xhtml?dcmi_identifier=BO-DS24781\&format $=$ xhtml

Reyes-García, V., Paneque-Gálvez, J., Bottazzi, P., Luz, A. C., Gueze, M., Macía, M. J., Orta-Martínez, M., Pacheco, P. (2014). Indigenous land reconfiguration and fragmented institutions: A historical political ecology of Tsimane' Llnds (Bolivian Amazon). Journal of Rural Studies, 34, 282-291. doi:10.1016/j.jrurstud.2014.02.007

Rist, S., Darr, B., \& Bottazzi, P. (2014). At the interface of culture, development, and forests: Insights from Bolivia and Kenya. In J. Pretzsch, Uibrig, H., \& Darr, D. (Eds.), Forests and rural development: Springer.

Sahlins, M. (2014). On the ontological scheme of beyond nature and culture. HAU: Journal of Ethnographic Theory, 4(1), 281-290. doi:10.14318/hau4.1.013

Schlosberg, D. (2013). Theorising environmental justice: The expanding sphere of a discourse. Environmental Politics, 22(1), 37-55. doi:10.1080/09644016.2013.755387

Scott, M. W. (2013). What I'm reading: The anthropology of ontology (religious science?). Journal of the Royal Anthropological Institute, 19(4), 859-872.

SERNAP, \& CRTM. (2019). Plan de manejo y plan de vida de la RB TCO Pilón Lajas. Servicio Nacional de Areas Protegidas and Consejo Regional Tsimane Mosetene.

Suchet-Pearson, S., Wright, S., Lloyd, K., \& Burarrwanga, L. (2013). Caring as country. Towards an ontology of co-becoming in natural resource management. Asia Pacific Viewpoint, 54(2), 185-197.

Surkin, J., Miranda, J. C., \& Miro, E. (2010). Corresponsabilidad en la gestión de los recursos naturales en Pilón Lajas. Retrieved from https://docplayer.es/39918567-Jordi-surkin-juan-carlos-miranda-y-edwin$\underline{\text { miro.html }}$

Svarstad, H., Benjaminsen, T. A., \& Overå, R. (2018). Power theories in political ecology. Journal of Political Ecology, 25(1), 350-363. https://doi.org/10.2458/v25i1.23044

Umans, L., \& Arce, A. (2014). Fixing rural development cooperation? Not in situations involving blurring and fluidity. Journal of Rural Studies, 34, 337-344. doi:10.1016/j.jrurstud.2014.03.004

van der Velden, M. (2005). Programming for cognitive justice. Towards an ethical framework for democratic code. Interacting with Computers, 17, 105-120.

van der Velden, M. (2009). Design for a common world: On ethical agency and cognitive justice. Ethics and Information Technology, 11(1), 37-47.

Visvanathan, S. (2005). Knowledge, justice and democracy. In M. Leach, I. Scoones, \& B. Wynne (Eds.), Science and citizens: Globalization and the challenge of engagement (pp. 83-85). Zed Books.

Viveiros de Castro, E. (1998). Cosmological deixis and Amerindian perspectivism. The Journal of the Royal Anthropological Institute, 4(3), 469-488.

Viveiros de Castro, E. (2004a). Exchanging perspectives: The transformation of objects into subjects in Amerindian ontologies. Common Knowledge, 10(3), 463-484.

Viveiros de Castro, E. (2004b). Perspectival anthropology and the method of controlled equivocation. Tipiti: Journal of the Society for the Anthropology of Lowland South America, 2(1), 2-22.

West, P., Igoe, J., \& Brockington, D. (2006). Parks and peoples: The social impact of protected areas. Annual Review of Anthropology, 35(1), 251-277. doi:10.1146/annurev.anthro.35.081705.123308

Zanotti, L., Carothers, C., Apok, C. A., Huang, S., Coleman, J., \& Ambrozek, C. (2020). Political ecology and decolonial research: co-production with the Iñupiat in Utqiagivik. Journal of Political Ecology, 27(1), 43-66. https://doi.org/10.2458/v27i1.23335

Zycherman, A. (2013). The changing value of food: Localizing modernity among the Tsimané Indians of Lowland Bolivia. PhD dissertation. Columbia University. 